\title{
Pengaruh Penerapan Model Pembelajaran Kooperatif Tipe Student Teams Achievement Division (STAD) Terhadap Hasil Belajar IPA Materi Energi Siswa Kelas IV SDN Kedung Sugo II Prambon-Sidoarjo.
}

\author{
Ira Puspita Sari \\ irapuspitasari@yahoo.co.id \\ Universitas PGRI Adi Buana Surabaya
}

\begin{abstract}
ABSTRAK
Penelitian ini bertujuan "untuk mengetahui validitas dan reliabilitas RPP yang digunakan sebagai perencanaan pembelajaran model pembelajaran kooperatif tipe Student Teams Achievement Division (STAD)" dan "untuk mengetahui ketuntasan belajar siswa kelas IV SD pada materi energi alternatif dengan menggunakan model pembelajaran kooperatif tipe Student Teams Achievement Division (STAD)". Penelitian ini termasuk penelitian kuantitatif. Adapun subyek dalam penelitian ini adalah siswa kelas IV SD Negeri Kedung Sugo II dengan sampel 32 siswa. Metode pengumpulan data yang digunakan adalah dengan menggunakan lembar validasi dan tes hasil belajar yang berjumlahkan 15 butir soal yang berbentuk 10 pilihan ganda dan 5 uraian pada kegiatan posttest yang dibandingkan dengan nilai KKM (kriteria ketuntasan minimal) yang ditentukan oleh pihak sekolah yaitu 70 untuk mata pelajaran IPA.

Dari hasil analisis didapatkan bahwa hasil validitas dari dua validator dengan nilai rata-rata validator pertama 4,27 , dan validator kedua 4,14 dikatakan sangat baik dan dapat digunakan dengan sedikit revisi dan untuk penghitungan reliabilitas RPP dikatakan baik mencapai 98,5\%. Rata-rata hasil belajar IPA menggunakan model pembelajaran kooperatif tipe Student Teams Achievement Division (STAD) lebih tinggi dibanding dengan nilai KKM, dan diperoleh taraf signifikan uji thitung $=6,16>$ tabel $=2,042$ Maka hipotesis nol ditolak Sehingga dapat disimpulkan ada pengaruh penerapan model pembelajaran kooperatif tipe Student Teams Achievement Division (STAD) terhadap hasil belajar IPA materi energi siswa kelas IV SDN Kedung Sugo II. Hal ini dibuktikan hanya 28 siswa dari 32 siswa yang mencapai nilai diatas KKM, dan 4 siswa yang nilainya dibawah KKM.
\end{abstract}

Kata Kunci: Kooperatif, Student Teams Achievement Division (STAD), hasil belajar. 


\section{A. Pendahuluan}

Di era globalisasi seperti saat ini ilmu pengetahuan dan teknologi sangatlah berperan penting dalam kelangsungan kehidupan manusia, akan tetapi banyak masalah yang dihadapi bangsa Indonesia, demikian pula dunia pendidikan. Profesionalisme seorang guru sangatlah dituntut dalam kegiatan belajar mengajar (KBM) dalam kelas, dimana guru harus kreatif dalam menggunakan metode atau menggunakan pendekatan yang tepat, sehingga dapat membangkitkan minat dan semangat belajar siswa.

Berdasarkan hasil observasi yang telah dilakukan pada SD Negeri Kedung Sugo II Tanggal 19 April 2011 ditemukan bahwa hasil belajar siswa rendah disebabkan oleh beberapa faktor diantaranya model pembelajaran yang digunakan oleh guru, dan rata-rata hasil belajar siswa yang mencapai 60 sedangkan nilai ketuntasan (KKM) yang harus di capai yaitu 70 .

Pembelajaran

Ilmu

Pengetahuan Alam (IPA) tersebut masih kurang mengaktifkan siswa. Hal ini ditunjukkkan dengan aktifitas siswa yang hanya duduk diam dan hanya mendengar penjelasan dari guru. Siswa merasa cepat jenuh dan bosan untuk mengikutinya apabila guru dalam proses pembelajaran hanya menggunakan metode ceramah, dan pemberian tugas saja. Siswa kurang menanggapi saat guru mengajukan pertanyaan atau meminta pendapat mereka. Siswa terlihat sibuk dengan urusannnya sendiri yaitu menggambar dan membolak-balikkan buku tanpa dibaca. Sedangkan pembelajaran Ilmu Pengetahuan Alam (IPA) yang diharapkan adalah menjadi wahana bagi siswa untuk mempelajari diri sendiri dan alam sekitar, serta pengembangan lebih lanjut dalam menerapkannya di kehidupan sehari-hari. Karena proses pembelajaran Ilmu Pengetahuan Alam (IPA) menekankan pada pemberian pengalaman langsung untuk mengembangkan potensi agar menjelajahi dan memahami alam sekitar secara ilmiah.

Gagasan utama dari Student Teams Achievement Division (STAD) ialah untuk memotivasi siswa supaya dapat saling mendukung dan membantu satu sama lain dalam menguasai kemampuan yang di ajarkan oleh guru. Para siswa bekerja sama setelah guru menyampaikan materi pelajaran, mereka harus melakukan yang terbaik menunjukkan norma bahwa 
belajar itu penting, berharga, dan menyenangkan, model ini dianggap ampuh dalam pengajaran. Oleh karena itu, setelah pembelajaran berlangsung, guru harus mengadakan evaluasi dalam bentuk kuis untuk mengetahui tingkat keberhasilan masingmasing siswa dalam menerima materi yang telah dipelajarinya selama mengikuti pembelajaran. Biasanya kriteria keberhasilan proses pembelajaran diukur dari sejauh mana siswa dapat menguasai materi yang disampaikan guru.

Berdasarkan uraian latar belakang di atas, maka pertanyaan yang dirumuskan adalah:

1. Bagaimana validitas dan reliabilitas Rencana

Pelaksanaan Pembelajaran (RPP) kooperatif tipe Student Teams Achievement Division (STAD) pada materi energi siswa kelas IV SDN Kedung Sugo II Prambon-Sidoarjo yang digunakan dalam penelitian ini?

2. Adakah pengaruh penerapan model pembelajaran kooperatif tipe Student Teams Achievement Division (STAD) terhadap hasil belajar IPA materi energi siswa kelas IV SDN Kedung Sugo II Prambon-Sidoarjo?

Sesuai rumusan pertanyaan di atas maka tujuan penulisan yang ingin di capai adalah:
1. Untuk mengetahui validitas dan reliabilitas Rencana Pelaksanaan Pembelajaran (RPP) kooperatif tipe Student Teams Achievement Division (STAD) pada materi energi siswa kelas IV SDN Kedung Sugo II Prambon-Sidoarjo yang digunakan dalam penelitian ini.

2. Untuk mengetahui pengaruh penerapan model pembelajaran kooperatif tipe Student Teams Achievement Division (STAD) terhadap hasil belajar IPA materi energi siswa kelas IV SDN Kedung Sugo II Prambon-Sidoarjo.

Hasil dari penelitian ini akan memberikan manfaat yang berarti yaitu sebagai berikut:

1. Bagi Siswa

Dapat mempermudah siswa dalam mempelajari materi energi alternatif melalui model pembelajaran kooperatif tipe Student Teams Achievement Division (STAD) dalam mengembangkan

ketrampilan, kerjasama, berdiskusi, menyampaikan pendapat, ketrampilan berfikir dan meningkatkan keterampilan sosial siswa.

2. Bagi Guru 
Hasil penelitian ini diharapkan dapat dijadikan sebagai salah satu bahan pertimbangan mengenai model pembelajaran yang digunakan dalam proses pembelajaran IPA pada materi energi khususnya energi alternatif.

3. Bagi Sekolah

Hasil penelitian ini diharapkan dapat dijadikan sebagai alternatif pembelajaran dalam rangka perbaikan proses pembelajaran untuk meningkatkan keaktifan dan hasil belajar siswa.

4. Bagi Peneliti

Hasil penelitian ini akan menambah pengetahuan alam dan ketrampilan peneliti mengenai model pembelajaran kooperatif tipe STAD (Student Teams Achievement Division).

Penelitian yang dapat dijadikan kajian dalam penelitian ini adalah:

1. Berdasarkan hasil penelitian Veronika Aprianingrum "Penerapan model pembelajaran kooperatif tipe Student Teams Achievement Division STAD dalam pembelajaran IPS untuk meningkatkan hasil belajar siswa kelas IV SDN Kedurus 1 Surabaya" Universitas
Negeri Surabaya Tahun

2011. Guru mampu mengelola pembelajaran dengan pendekatan keterampilan proses dalam seting pembelajaran kooperatif tipe Student Teams Achievement Division STAD dengan baik, dan mampu melatihkan dan mengoperasikan dengan baik perangkat pembelajaran sesuai dengan alokasi waktu yang ditentukan, serta membuat siswa antusias dalam mengikuti pembelajaran.

2. Berdasarkan hasil penelitian Ria Kumala Sari "Efektifitas pembelajaran Kooperatif tipe Student Teams Achievement Division STAD pada pelajaran matematika ditinjau dari kemandirian siswa kelas VIII SMP 1 Negeri Sukoharjo". Pembelajaran dengan pendekatan keterampilan proses dalam seting pembelajaran kooperatif tipe Student Teams Achievement Division STAD dapat mengubah pembelajaran dari teacher center menjadi student centered.

Kajian teori yang dapat peneliti paparkan adalah sebagai berikut: 
1. Model Pembelajaran Kooperatif

a. Pengertian Pembelajaran Kooperatif

Menurut

Trianto

(2007:41) pembelajaran yang bernaung dalam teori konstruktivis adalah kooperatif. Pembelajaran kooperatif muncul dari konsep bahwa siswa akan lebih mudah menemukan dan memahami konsep yang sulit jika mereka saling berdiskusi dengan temannya. Siswa secara rutin bekerja dalam kelompok untuk saling membantu memecahkan masalahmasalah yang kompleks. Jadi, hakikat sosial dan penggunaan kelompok sejawat menjadi aspek utama dalam pembelajaran kooperatif.

b. Fase-Fase Pembelajaran Kooperatif

\section{Pengertian Student Teams}

\section{Achievement Division} (STAD)

Slavin, Nur (dalam

Trianto, 2007:52) pada Student Teams Achievement Division (STAD) siswa ditempatkan dalam tim belajar beranggotakan 4-5 orang yang merupakan campuran menurut tingkat prestasi, jenis kelamin, dan suku. Guru menyajikan pelajaran, dan kemudian siswa bekerja dalam tim mereka memastikan bahwa seluruh anggota tim telah telah menguasai pelajaran tersebut. Kemudian seluruh siswa diberikan tes tentang materi tersebut, pada saat tes mereka tidak dapat diperbolehkan membantu.

Langkah-Langkah pembelajaran kooperatif tipe Student Teams Achievement Division (STAD) sebagai berikut:

1. Persiapan
a. Menyiapkan Materi
b. Pembentukan Kelompok Siswa
c. Menentukan skor dasar siswa
d. Menentukan jadwal kegiatan

2. Penyajian Materi
a. Pendahuluan
b. Menjelaskan materi
c. Latihan terbimbing

3. Kegiatan Kelompok

4. Kuis/Evaluasi
a. Siswa
diminta mempresentasikan hasil diskusi
kelompoknya.
b. Membagikan lembar kuis kepada siswa dan dikerjakan mandiri. Setelah siswa diberikan kuis, 
5. Penghargaan

$$
\begin{aligned}
& \text { guru menghitung } \\
& \text { skor individu (skor } \\
& \text { perkembangan). }
\end{aligned}
$$

a. Menghitung skor individu

b. Menghitung Skor Kelompok

c. Pemberian hadiah dan pengakuan skor kelompok setelah masing-masing kelompok memperoleh predikat, guru memberikan hadiah atau penghargaan kepada masing-masing kelompok sesuai dengan predikatnya.

3.

\section{engertian Hasil Belajar}

Menurut Aburahman (dalam Jihat, 2008:14) "hasil belajar adalah kemampuan yang diperoleh anak setelah melalui kegiatan belajar". Berdasarkan uraian diatas, seseorang dapat dikatakan belajar karena adanya indikasi melakukan proses tersebut secara sadar dan menghasilkan perubahan tingkah laku siswa yang diperoleh berdasarkan interaksi dengan lingkungan.

Sedangkan menurut Hamalik (dalam Jihat, 2008:15) "hasil belajar adalah pola-pola perbuatan, nilai-nilai, pengertianpengertian dan sikap-sikap serta apersepsi dan abilitas".

Dari beberapa uraian pendapat tersebut dapat disimpulkan bahwa pengertian hasil belajar adalah perubahan tingkah laku siswa secara nyata setelah dilakukan proses belajar-mengajar yang sesuai dengan tujuan pembelajaran yang dicapai. Berkaitan dengan tujuan pembelajaran adalah penunjukkan bahwa siswa telah melakukan proses pembelajaran yang meliputi tahap pengetahuan, ketrampilan dan sikap-sikap yang baru yang diharapkan harus dicapai oleh siswa.

\section{Pengertian Ilmu Pengetahuan} Alam (IPA)

a. Pengertian Ilmu Pengetahuan $\mathbf{P}$ Alam (IPA)

Menurut Kardi dan Nur (dalam Trianto, 2008:61 ) mengatakan bahwa, Sains atau ilmu kealaman adalah ilmu tentang dunia zat, baik makhluk hidup maupun benda mati yang diamati.

Sedangkan menurut Wahyana (dalam Trianto, 2008:61) mengatakan bahwa sains adalah suatu kumpulan pengetahuan tersusun secara sistematik, dan dalam penggunaannya secara umum terbatas pada gejala-gejala alam.

Dari penjelasan diatas dapat disimpulkan bahwa Sains adalah ilmu pengetahuan yang terdiri atas teori yang sistematis, umumnya penerapannya 
terbatas pada gejala alam, dan dan berkembang melalui metode ilmiah serta menuntut sikap yang ilmiah

Karakteristik

Pembelajaran Ilmu

Pengetahuan Alam (IPA)

b. Ilmu pengetahuan alam sebagai pengetahuan yang diperoleh melalui pengumpulan data dengan eksperimen, pengamatan dan deduksi untuk menghasilkan suatu penjelasan tentang sebuah gejala yang dapat dipercaya. Ada tiga kemampuan dalam Ilmu Pengetahuan Alam (IPA) yaitu; kemampuan untuk mengetahui apa yang diamati, kemampuan untuk memprediksi apa yang diamati, dan kemampuan untuk menguji tindak lanjut hasil eksperimen, dikembangnya sikap ilmiah.

c. Tujuan Pembelajaran Ilmu Pengetahuan Alam (IPA)

Menurut Depdiknas (dalam Trianto, 2010:143) hakikat dan tujuan pembelajaran Ilmu Pengetahuan Alam (IPA) diharapkan dapat memberikan antara lain sebagai berikut:

1) Kesadaran akan keindahan dan keteraturan alam untuk meningkatkan keyakinan terhadap Tuhan Yang Maha Esa.

2) Pengetahuan, yaitu pengetahuan tentang dasar dari prinsip dan konsep, fakta yang ada di alam, hubungan saling ketergantungan, dan hubungan antara sains dan teknologi.

3) Keterampilan dan kemampuan untuk menangani peralatan, memecahkan masalah dan melakukan observasi.

4) Sikap ilmiah, antara lainskeptis, kritis, sensitive, obyektif, jujur terbuka, benar, dan dapat bekerja sama.

5) Kebiasaan mengembangkan kemampuan berfikir analitis induktif dan deduktif dengan menggunakan konsep dan prinsip sains untuk menjelaskan berbagai peristiwa alam.

6) Apresiatif terhadap sains dengan menikmati dan menyadari keindahan keteraturan perilaku alam 
serta penerapannya dan teknologi.

Menurut Kurikulum

Pendidikan Dasar dalam

Garis-garis Besar Program

Pengajaran (GBPP) Sekolah

Dasar dinyatakan bahwa

tujuan pembelajaran Ilmu

Pengetahuan Alam atau

Sains http: //id.

shvoong.com/ social-

sciences/education/2120776-

tujuanpembelajaran-ilmu

pengetahuan-alam Diakses

24 Mei 2011 adalah sebagai berikut:

a) Menanamkan rasa ingin tahu dan suatu sikap positif terhadap teknologi dan masyarakat.

b) Mengembangkan

keterampilan proses untuk menyelidiki alam sekitar, memecahkan masalah dan membuat keputusan.

c) Menanamkan

pengetahuan dan

pemahaman konsep-

konsep sains yang akan

bermanfaat dan dapat

diterapkan dalam

kehidupan sehari-hari.

d) Mengembangkan

kesadaran tentang peran

dan pentingnya sains kehidupan sehari-hari. e) Mengalihgunakan

pengetahuan,

keterampilan, dan

pemahaman kebidang

pengajaran lainnya.

f) Ikut serta dalam memelihara, menjaga dan melestarikan lingkungan alam.

g) Menghargai ciptaan Tuhan akan lingkungan alam.

Maksud dan tujuan tersebut adalah agar anak memiliki pengetahuan tentang gejala alam dan berbagai jenis dan peran lingkungan alam dari lingkungan buatan dengan melalui pengamatan agar anak tidak buta dengan pengetahuan dasar mengenai IPA atau Sains.

\section{Materi}

Energi alternatif adalah energi yang bukan berasal dari bahan bakar fosil. Sesungguhnya alam menyediakan berbagai energi alternatif yang tidak akan pernah habis.

a. Sumber Energi Alternatif

1) Matahari

2) Angin

3) Panas Bumi

b. Keuntungan Penggunaan Energi Alternatif 
Sumber energi alternatif memiliki keuntungan sebagai berikut:

1) Sumber energi alternatif dapat terus digunakan

2) Energi yang dihasilkan oleh sumber energi alternatif sangat besar

3) Energi alternatif tidak mencemari lingkungan karena tidak menghasilkan zat-zat buangan ke lingkungan.

c. Kesulitan Dalam Pemanfaatan Energi Alternatif

1) Dibutuhkan biaya yang sangat besar untuk dapat memanfaatkan energi alternatif

2) Dibutuhkan teknologi tinggi untuk mengubah enrgi alternatif menjadi energi yang dapat digunakan.

3) Tersedianya energi alternatif dipengaruhi oleh musim.

\section{B. Metode}

Pendekatan Penelitian yang digunakan adalah penelitian kuantitatif. Rancangan penelitian yang digunakan pada penelitian ini adalah One Shot-Case Study yaitu penelitian yang dilakukan dengan melaksanakan suatu perlakuan tertentu kepada subyek pada saat perlakuan dan pengukuran terhadap akibat dari perlakuan tersebut. Rancangan penelitian dapat dilihat pada gambar sebagai berikut:

1. Populasi

Menurut

Arikunto (2010:173) "Populasi adalah keseluruhan subyek penelitian. Berdasarkan pengertian populasi di atas maka populasi dalam penelitian ini adalah siswa kelas IV SDN Kedung Sugo II dengan jumlah siswa 32 dengan perincian laki-laki 16 siswa dan perempuan 16 siswi.

2. Sampel.

Menurut

Arikunto (2010:174) bahwa Sampel adalah sebagian atau wakil populasi yang akan diteliti. Untuk menentukan sampel dalam penelitian ini peneliti menggunakan teknik sampel populasi adalah teknik penentuan sampel bila semua anggota populasi digunakan sebagai sampel Sugiyono (2010:82). Cara demikian dilakukukan karena anggota populasi di sekolah tersebut berjumlah 32 siswa. Dari pengertian dan alasan yang telah dikemukakan di atas maka sampel penelitian ini adalah siswa kelas IV SDN Kedung Sugo II dengan jumlah siswanya 32. Jenis metode yang dipilih oleh peneliti adalah lembar validasi dan metode tes. 
Berdasarkan rumusan

pertanyaan yang telah

dirumuskan peneliti diatas

perlu adanya analisis data

sebagai berikut:

$\begin{array}{lrr}\text { 1. Analisis } & \text { validitas } & \text { dan } \\ \text { reliabilitas } & \text { RPP } & \text { untuk } \\ \text { rumusan } & \text { pertanyaan } \\ \text { pertama } & & \end{array}$

a. Validitas

Perangkat pembelajaran dalam penelitian ini divalidasi oleh dua orang validator difokuskan pada aspek isi, bahasa dan format, bahwa perangkat pembelajaran sudah valid serta layak digunakan tanpa revisi.

b. Reliabilitas

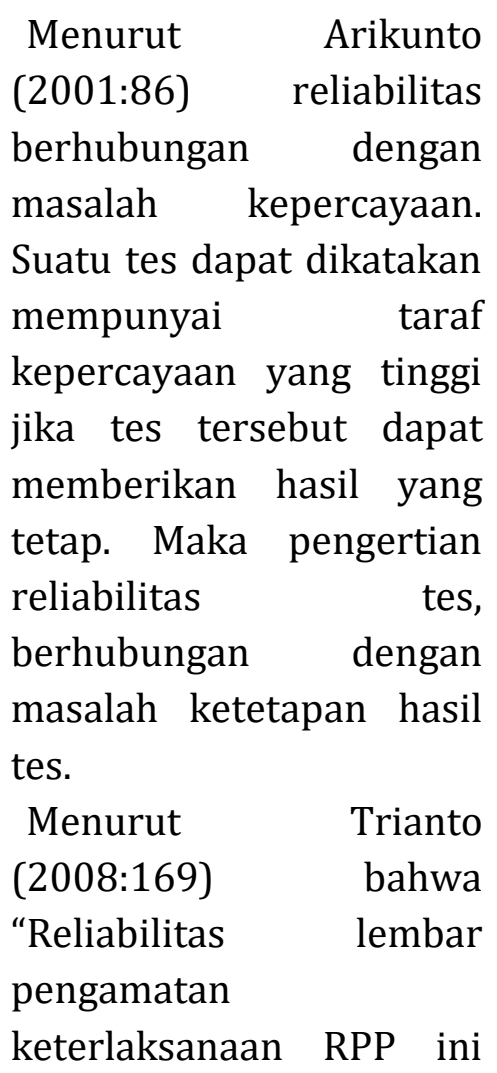

diuji dengan rumus

sebagai berikut :

Reliabilitas $=$

$100 \%\left[1-\frac{A-B}{A+B}\right]$

Keterangan :

A : Frekuensi aspek tingkah laku yang teramati oleh pengamat yang memberikan frekuensi tinggi

B : Frekuensi aspek tingkah laku yang teramati oleh pengamat yang memberikan frekuensi tinggi

Instrumen dikatakan baik jika mempunyai koefisien reliabilitas $\geq$ 0,75 atau $75 \%$.

2. Analisis tes untuk rumusan pertanyaan ke dua

Pada penelitian ini tes diberikan sekali yaitu tes setelah pembelajaran berlangsung (post-Test).

$\tau=\frac{\bar{X}-\mu_{0}}{\frac{s}{\sqrt{n}}}$

(Pramesti, 2007:38)

Keterangan :

$\bar{X} \quad$ : Rata-rata hasil

belajar IPA

S : Simpangan baku

$\mu_{0} \quad$ : Kriteria ketuntasan minimal (KKM)

n : Subjek pada sampel 
Uji-t digunakan untuk menguji, suatu nilai tertentu yang diberikan sebagai pembanding yang berbeda secara nyata atau tidak dengan rata-rata populasi.

\section{Hasil}

Data yang diperoleh dalam penelitian ini berupa data kuantitatif. Jadi pengolahan data dapat di sajikan sebagai berikut:

1. Hasil validasi dan reliabilitas Rencana Pelaksanaan Pembelajaran dengan menggunakan model pembelajaran Kooperatif tipe Student Teams Achievement Division (STAD). Pada validator pertama ratarata yang diperoleh adalah 4,27, dan validator kedua rata-rata yang diperoleh adalah 4,14.

Adapun rumus yang akan digunakan dalam mereliabilitas RPP adalah sebagai berikut :

Reliabilitas $100 \%\left\lfloor 1-\frac{A-B}{A+B}\right\rfloor$

Dengan diketahui A: 4,27

$$
\text { B : } 4,14
$$

Maka dapat dihitung reliabelitas RPP

Reliabilitas $=$

$100 \%\left[1-\frac{A-B}{A+B}\right]$

$$
\begin{aligned}
& \begin{array}{c}
= \\
\left\lfloor 1-\frac{4,27-4,14}{4,27+4,14}\right\rfloor
\end{array} \\
& =100 \%\left[1-\frac{0,13}{8,41}\right] \\
& =100 \\
& \text { [1 - 0,015] } \\
& =100 \%(0,985) \\
& =98,5 \%
\end{aligned}
$$

2. Tes Hasil Belajar Siswa (Uji-t)

a. Mencari simpangan baku terlebih dahulu sebelum menghitung uji-t sebagai berikut:

$$
\begin{aligned}
\sum X^{2} d & =4005,469 \\
\mathrm{~N} & =32 \\
\mathrm{~S} & =\sqrt{\frac{\sum\left(x_{i}-\bar{x}\right)^{2}}{n-1}} \\
& =\sqrt{\frac{4005,469}{32-1}} \\
& =\sqrt{\frac{129,21}{31}} \\
& =\sqrt{98,21} \\
& =9,91
\end{aligned}
$$

b. Dengan perhitungan simpangan baku, maka nilai uji-t dapat ditentukan sebagai berikut:

$$
\begin{aligned}
& \tau=\frac{\bar{X}-\mu_{0}}{\frac{s}{\sqrt{n}}} \\
& =\frac{80, / 8-70}{\frac{g, s 2}{\sqrt{s n}}}
\end{aligned}
$$




$$
\begin{aligned}
& =\frac{10,78}{\frac{5,91}{\sqrt{s 2}}} \\
= & \frac{10,78}{\frac{5,14}{5,66}} \\
= & \frac{10, / 8}{1, / 5} \\
= & 6,16
\end{aligned}
$$

c. Menentukan kriteria pengujian hipotesis pada ttabel adalah sebagai berikut:

$$
\begin{aligned}
t_{\text {tabel }} & =\mathrm{t} \frac{\omega}{2}(\mathrm{n}-1) \\
& =\mathrm{t} \frac{\mathrm{U}, \mathrm{U}_{\mathrm{s}}}{2}(32-1) \\
& =\mathrm{t} 0,025(31) \\
& =2,042
\end{aligned}
$$

Ho ditolak jika thitung $<-2,042$ atau $t_{\text {tabel }}>2,042$

Dari analisis di dapat $\mathrm{t}$ hitung $=6,16$. Untuk menguji hipotesis, kita kembali ke Ho dan kemudian $t$ hitung dikonsultasikan dengan $t$ tabel dengan keabsahan (dk): $\mathrm{n}-1=32-1=31$ dan taraf signifikansi 0,05 di dapat $t$ tabel sebesar 2,042. Dengan demikian nilai $\mathrm{t}$ hitung lebih besar dari pada nilai $t$ tabel yaitu 6,16 > 2,042 Maka hipotesis nol ditolak Sehingga dapat disimpulkan ada pengaruh penerapan model pembelajaran kooperatif tipe Student Teams Achievement Division (STAD) terhadap hasil belajar IPA materi energi alternatif siswa kelas IV SDN

Kedung Sugo II

\section{Pembahasan}

Berdasarkan data validitas, Rencana Pelaksanaan Pembelajaran (RPP) yang akan digunakan dengan memperhatikan beberapa aspek yang dinilai dapat dikategorikan sangat baik dengan rata-rata pada aspek penilaian format 4,25 , aspek penilaian isi 4,18 , dan pada aspek penilaian Bahasa 4,25. Pada penghitungan Reliabilitas Rencana Pelaksanaan Pembelajaran (RPP) yang diperoleh peneliti maka Rencana Pelaksanaan Pembelajaran (RPP) yang digunakan dapat dikatakan baik untuk diterapkan karena mempunyai lebih dari sama dengan $75 \%$. adapun perolehan koefisien dengan prosentase $98,5 \%$.

Hasil uji hipotesis dengan uji $\mathrm{t}$ memperoleh $\mathrm{t}_{\text {hitung variabel }}$ model pembelajaran kooperatif tipe Student Teams Achievement Division (STAD) sebesar 6,16 lebih besar dari table 2,042 pada taraf signifikansi 5\%. Artinya $\mathrm{H}_{0}$ dinyatakan ditolak, yaitu bahwa model pembelajaran kooperatif tipe Student Teams Achievement Division (STAD) berpengaruh positif terhadap hasil belajar IPA materi energi siswa kelas IV SDN Kedung Sugo II. 
Hal ini dibuktikan dari jumlah siswa 32, dari 28 siswa yang memenuhi nilai diatas kriteria ketuntasan minimal (KKM), dan 4 siswa yang nilainya dibawah kriteria ketuntasan minimal (KKM).

\section{E. Penutup: Simpulan dan Saran}

\section{A. Simpulan}

Berdasarkan pembahasan yang telah dilakukan maka dapat ditarik kesimpulan sebagai berikut :

1. Validitas dan reliabilitas Rencana Pelaksanaan Pembelajaran (RPP) kooperatif tipe Student Teams Achievement Division (STAD) pada materi energi siswa kelas IV SDN Kedung Sugo II Prambon-Sidoarjo yang digunakan dalam penelitian ini dinyatakan valid dan dapat digunakan kelayakannya serta dikategorikan sangat baik dari berbagai aspek penilaian.

2. Ada pengaruh penerapan model pembelajaran kooperatif tipe Student Teams Achievement Division (STAD) terhadap hasil belajar IPA materi energi siswa kelas IV SDN Kedung Sugo II Prambon-Sidoarjo.

\section{B. Saran}

Berdasarkan simpulan di atas maka peneliti dapat mengajukan saran-saran sebagai berikut:

1. Dalam penerapan model kooperatif tipe Student Teams Achievement Division (STAD) perlu mempertimbangkan waktu pelaksanaan kegiatan pembelajaran karena pembelajaran model kooperatif tipe Student Teams Achievement Division (STAD) ini cukup memakan banyak waktu khususnya pada waktu siswa harus melakukan percobaan.

2. Penerapan model kooperatif tipe Student Teams Achievement Division (STAD) dapat meningkatkan hasil belajar siswa apabila siswa lebih memahami langkahlangkah pembelajaran dan membagi waktu yang baik.sehingga siswa tidak kualahan dalam melaksanakannya terlebih saat membagi siswa dalam kelompok.

3. Dalam kegiatan aktif seperti diskusi kelompok, hendaknya siswa dapat saling menghormati pendapat dari masingmasing siswa sehingga apa yang didiskusikan dapat mengerucut ke kesimpulan 
yang tepat. Untuk itu perlu bimbingan dan panduan guru agar tujuan kerja kelompok atau diskusi dapat tercapai.

\section{F. Daftar Pustaka}

Arikunto, Suharsimi. 2001. DasarDasar Evaluasi Pendidikan (Edisi Revisi). Jakarta: Bumi Aksara

Arikunto, Suharsimi. 2006. Prosedur Penelitian Suatu Pendekatan Praktik. Jakarta: PT. Rineka Cipta

Arikunto, Suharsimi. 2010. Prosedur Penelitian Suatu pendekatan Praktek, Jakarta : Rineka Cipta.

Asep Jihad dan Abdul Haris. 2008. Evaluasi Pembelajaran . Yogyakarta: Multi Presindo Aprianingrum, Veronica "Penerapan model pembelajaran kooperatif tipe Student Team Activement Division STAD dalam pembelajaran IPS untuk meningkatkan hasil belajar siswa kelas IV SDN Kedurus 1 Surabaya". Skripsi. Universitas Negeri Surabaya Tahun 2011

Fanani, Achmad. Dwi Retnani S. Bahaudin Azmy. and, Rarasaning Setianingsih. 2010. Pedoman Skripsi dan Standar Operasional Prosedur (SOP)
Pemrograman Skripsi

Mahasiswa PGSD Program

Studi Pendidikan Guru

Sekolah Dasar Fakultas

Keguruan dan Ilmu

Pendidikan Universitas PGRI

Adi Buana Surabaya 2010.

Surabaya.

http://id.shvoong.com/social-

sciences/education/21207

76-tujuan-pembelajaran-

ilmu-pengetahuan-alam

Diakses 24 Mei 2011

http://yankcute.blogspot.com/20

10/02/keunggulan-dan-

kekurangan

pembelajaran.html Diakses pada 24 Mei 2011.

Kumala Sari, Ria"Efektifitas pembelajaran Kooperatif tipe Student Team Activement Division STAD pada pelajaran matematika ditinjau dari kemandirian siswa kelas VIII SMP 1 Negeri Sukoharjo". Skripsi.

Pramesti, Wara and sunardi Hartanto. 2008. Statistika. Surabaya: University Press Adi Buana Surabaya.

Purwanto. 2009. Evaluasi Hasil Belajar. Yogyakarta: Pustaka Belajar

Rositawati, S. dkk. 2008. Senang belajar ilmu pengetahuan alam. Jakarta: Pusat perbukuan Departemen Pendidikan Nasional. 
Suprijono, Agus. 2009. Cooperative

Trianto.

2007.

Model

Learning. Yogyakarta:

Pembelajaran Terpadu

Pustaka Pelajar.

Slameto, 2010. Belajar \& Faktor-

dalam Teori dan Praktek.

Faktor

yang

Mempengaruhinya. Jakarta:

PT Asdi Mahasatya

Jakarta: Prestasi Pustaka

Trianto. 2008. Pembelajaran

Kontekstual (Contextual

Teaching and Learning) di

Trianto. 2007. Model Model Pembelajaran Inovatif Kelas. Jakarta: Cerdas Pustaka Publisher.

Berorientasi Trianto. 2010. Model

Konstruktivistik. Jakarta:

Prestasi Pustaka

Pembelajaran Terpadu.

Jakarta: Bumi Aksara 